\title{
THREE MODELS OF NET METROPOLITAN MIGRATION\#
}

\author{
Michael J. White*
}

\section{INTRODUCTION}

A major shortcoming of existing research on human migration is its lack of comparability. Widely different sets of explanatory variables, demographic groups, geographic units, and sample sizes have been used. Often the absence of explicit disciplinary theory makes it difficult to interpret these findings or make any confident generalizations or predictions about population shifts. In response to this weakness, this paper examines patterns of age-race specific net migration of males between United States metropolitan areas for 1960 to 1970 using three models of migration, each of which has a distinct conceptual underpinning. The first model draws on several neoclassical economic perspectives, the second discusses the influence of non-traded goods, and the third derives and tests an ecological model of migration. The following sections of the paper discuss the approach to the subject, outline the methodology and assumptions, and present each model and its results. The conclusion compares the models and finds some implications for further work.

\section{APPROACH AND DATA}

Migration is the principle means of population redistribution within and between regions. The reasons people move are extremely diverse and include job mobility, improved health and recreation, cultural environment, and return to family and friends. Migration is usually an act of individual or family decision-making based primarily on economic and social exigencies, but reflecting also cultural desires, concepts of "goods" and "bads," and the availability and interpretation of information. Even though decisions are made on a household basis, data that measure net or grouped flows can be used because many moves were made, at least in part, for similar reasons.

The considerable amount of extant research on internal migration has revealed several regularities about who migrants are. Propensity to migrate tends to decrease with age and family status. It is higher for those seeking work and for persons of greater educational attainment. The redistribution of abilities due to migration is usually interpreted as benefit- 
ting all members of the community in the long run. However, some concern has been given to the possibility that selective migration may lead to the persistence, or even widening, of existing regional disparities.

Although this work has produced a good deal of knowledge about the characteristics of migratory behavior, it still contains several deficiencies, among them:

(1) It generally lacks a proper marriage of an explicit theoretical foundation with careful empirical analysis. Except for the use of Ravenstein's laws and some gravity models, demographic analysis of migration has been primarily empirical and descriptive. On the other hand, economics has produced some predictive theories of migration, but these are less often tested in empirically-based research.

(2) Little work has been done with disaggregated data to test the dynamics of selective migration. In much available data, the geographical units of observation are frequently poorly defined. For instance, interstate migration records a move from New York City to its New Jersey suburbs, while ignoring a 450-mile journey from San Francisco to Los Angeles.

(3) Finally, and most important, there have been few tests of alternative models of mobility with the same set of data. As it is now, there is virtually no way of reconciling with certainty conflicting results obtained by many good studies, merely because the data involved census regions in one case, states in another, five-year mobility rates in one, one-year rates in another.

This paper attempts to respond to these criticisms by studying ten-year (1960-1970) internal net migration to each United States Standard Metropolitan Statistical Area (SMSA) for males, broken down by five-year age groups and race. The eight age groups are 25-29, 30-34, 35-39, 40-44, $45-49,50-59,60-69$, and 70+; these refer to 1970 ages of the members of the cohort. Cities missing data, including all those in New England, were omitted, as were five outliers. The data were constructed by the census survival ratio method and are due to Hinze. ${ }^{1}$ The results obtained here differ from his, however, in several important respects. These patterns of internal migration-the dependent variables-are examined in light of three distinct models of migratory behavior. All models for each age-race group are tested on the same sample of cities. For all whites, 206 cities comprise the sample; for blacks up to 44 additional cities that lacked a sufficient base population were omitted. The SMSA is the most appropriate spatial unit because it is constructed to reflect an economically and socially integrated area (an aggregate of coterminous counties), a functional community in the ecological sense. It comprises a single labor market area, and distinguishes intrametropolitan moves from intermetropolitan moves.

The use of age-race groups provides the opportunity to examine the migration of components of the population. Although female migration rates are not discussed in this paper, they do correspond very closely to those of males. Without the additional disaggregation of female rates by labor force participation and marital status, a great deal cannot be inferred about the independent redistribution patterns of women. It should be 
noted that with the necessary use of net migration rates here instead of gross rates, information is lost regarding the directional flows or volume of movement. To the extent that in-migrants differ from out-migrants, the aggregation may prevent notice of significant distributional shifts [13]. For the most part, end period economic measures are used here, because ten-year mobility rates are biased toward the end of the decade. Some models were tested with change over the decade as independent variable and these are discussed briefly.

All results were obtained through ordinary least squares regression. Preliminary versions of the models were tested for outliers, linearity in the relation of independent and dependent variables, etc. To assess the impact of regional effects beyond the given model, each was tested with and without dummy variables (for U.S. Census Regions South and West). An appendix which contains more details on the definitions and sources of variables, and lists the omitted cities, is available from the author upon request.

\section{NEOCLASSICAL ECONOMIC THEORY AND HUMAN CAPITAL}

One of the most basic models of migration is a straightforward outgrowth of neoclassical economic theory. In its most austere formulation (such as Hicks [7, p. 76]), the intermetropolitan movement of population should be only a function of current real wage differences existing in cities. When the labor market is in equilibrium (under standard assumptions of perfect competition, homogeneous labor supply, etc.), the wage received will equal the value of marginal physical product of labor, i.e., ${ }_{\mathrm{w}}^{\mathrm{A}}=\left(\mathrm{p}_{\mathrm{x}}^{\mathrm{A}}\right)\left(\mathrm{MPP}_{\mathrm{L}}^{\mathrm{A}}\right)$ where for a given region $\mathrm{A}, \mathrm{w}^{\mathrm{A}}$ is the wage rate, $\mathrm{p}_{\mathrm{x}}^{\mathrm{A}}$ is the product price, and $\mathrm{MPP}_{\mathrm{L}}^{\mathrm{A}}$ is the marginal physical product of labor in A. A similar equation can be written for region $B$. Under equilibrium conditions, then,

$$
w^{\mathrm{A}}=w^{\mathrm{B}} \text { and } \mathrm{p}_{\mathrm{X}}^{\mathrm{A}} / \mathrm{p}_{\mathrm{X}}^{\mathrm{B}}=\mathrm{MPP}_{\mathrm{L}}^{\mathrm{A}} / \mathrm{MPP}_{\mathrm{L}}^{\mathrm{B}}
$$

If the relation is not satisfied-a worker is being paid too much or too little for his productivity - there will be movement from one region to another in typical supply and demand adjustment until equilibrium is again attained. $^{2}$

The inclusion of wages alone in the analysis may be too restrictive, however. An exact equilibrium wage rate with full employment (implicit in the model above) is attained neither in every region nor nationally. An equally relevent impetus to movement may be the availability of jobs per se, which is best measured by the unemployment rate. The operation of unionism, government policy (e.g., minimum wage), age cohort maturation, social norms, and other factors make it very reasonable to expect a gap between the demand and supply of labor. The adjustment of supply and demand curves for labor in regions $\mathrm{A}$ and $\mathrm{B}$ will then be the result of migration, both for job search and for higher wages. 
There is a considerable amount of debate in the literature regarding (1) the interplay of pushes and pulls in the motivation to migrate, and (2) the time lag with which employment effects are felt. The first cannot properly be assessed with net migration data. Most studies have examined only the difference between origin and destination. Lowry, using gross migration data, found that this difference mattered but that wages and availability of employment in the destination had greater impact on migration [9, pp. 94-95]. The time lag question (especially with regard to unemployment) presents the more serious practical problem of whether to use beginning or end period rates in the regression equations, particularly when unemployment rates might vary substantially over a ten-year period. Recognizing this, several versions of the model were tested: (a) including the 1960 unemployment rate only, (b) including both the 1960 and 1970 figures, allowing for independent effects at each end of the time interval, and (c) including only the ten-year percent change in the local unemployment rate. For the most part these three versions gave comparable results, and we include (b) in Table 1. (Interestingly, the effect of the variable in (c) was dampened upon inclusion of the regional dummies because of a high correlation with them. $)^{3}$

Taxes may play a part in migration, although the effect is not so clearcut. On the one hand, taxes reduce an individual's disposable income, while on the other, they provide the opportunity for increased consumption of public goods. Outmigration among individuals who perceive that they derive little benefit from local public goods in relation to their rate of taxation might be expected, then, and inmigration to certain cities among those for whom local public services provide a great deal of utility in relation to income foregone. Such tendencies to migrate interregionally will be weakened by the fact that movers can usually choose between the municipalities within any metropolitan area which offer different and "competing" packages of public services and tax rates in a Tiebout-type economy [14]. Still, effects of this kind may occur between regions, and where variations appear across age and race groups, the regression equations should reveal them.

An economic theory of more recent vintage that has been aptly applied to the migration discussion is that of "human capital." The prospective migrant is considered to be a rational decision maker who takes into account the future stream of costs and benefits that accrue to alternative locations, career decisions, etc. Becker contends that just as there is investment in manufacturing plants and machinery, there is also investment in human capital by means of "activities that influence future real income through the imbedding of resources in people" [1, p. 9]. Through schooling, for example, an individual foregoes current earnings in order to gain employment opportunities and greater earnings in the future.

In monetary terms the expected benefits of a future time must be discounted to their present value since they cannot be currently consumed. Thus, a potential migrant in city A considers his present status in terms of occupation and income in $\mathrm{A}$, and compares it with alternative occupations 
TABLE 1. Model I-Earnings and Unemployment

\begin{tabular}{|c|c|c|c|c|c|c|c|c|c|c|}
\hline $\begin{array}{l}\text { AGE } \\
\text { GROUP }\end{array}$ & PROFM70+ & LABM70+ & CLERF70+ & TAX67 & UNRT60 & UNRT70 & SOUTH & WEST & Const. & $\mathrm{R}^{2} /(\mathrm{N})$ \\
\hline \multicolumn{11}{|c|}{ White Males } \\
\hline $25-29$ & $\begin{array}{l}1.194 * * * \\
(0.218)\end{array}$ & $\begin{array}{c}-0.355 \\
(0.218)\end{array}$ & $\begin{array}{c}0.497 \\
(0.503)\end{array}$ & $\begin{array}{r}-0.030 \\
(0.046)\end{array}$ & $\begin{array}{c}-5.508 * * * \\
(1.168)\end{array}$ & $\begin{array}{c}-0.510 \\
(1.520)\end{array}$ & $\begin{array}{c}8.328 \\
(4.555)\end{array}$ & $\begin{array}{c}17.252^{* * *} \\
(5.120)\end{array}$ & -89.386 & $0.461 /(206)$ \\
\hline $30-34$ & $\begin{array}{l}1.353 * * * \\
(0.262)\end{array}$ & $\begin{array}{c}0.519 \\
(0.262)\end{array}$ & $\begin{array}{c}-0.500 \\
(0.604)\end{array}$ & $\begin{array}{c}0.002 \\
(0.055)\end{array}$ & $\begin{array}{c}0.497 \\
(1.404)\end{array}$ & $\begin{array}{c}-3.418 \\
(1.826)\end{array}$ & $\begin{array}{r}10.815^{*} \\
(5.473)\end{array}$ & $\begin{array}{r}12.634^{*} \\
(6.153)\end{array}$ & -129.954 & $0.321 /(206)$ \\
\hline $35-39$ & $\begin{array}{l}0.631^{* * *} \\
(0.146)\end{array}$ & $\begin{array}{c}0.176 \\
(0.146)\end{array}$ & $\begin{array}{c}0.076 \\
(0.337)\end{array}$ & $\begin{array}{r}-0.063 * \\
(0.031)\end{array}$ & $\begin{array}{c}-0.104 \\
(0.783)\end{array}$ & $\begin{array}{r}-2.288^{*} \\
(1.019)\end{array}$ & $\begin{array}{r}4.999 \\
(3.053)\end{array}$ & $\begin{array}{c}17.744 * * * \\
(3.432)\end{array}$ & -63.125 & $0.293 /(206)$ \\
\hline $40-44$ & $\begin{array}{l}0.316^{* *} \\
(0.115)\end{array}$ & $\begin{array}{c}-0.014 \\
(0.115)\end{array}$ & $\begin{array}{c}0.119 \\
(0.265)\end{array}$ & $\begin{array}{r}-0.054^{*} \\
(0.024)\end{array}$ & $\begin{array}{c}-0.470 \\
(0.616)\end{array}$ & $\begin{array}{r}1.842 * \\
(0.802)\end{array}$ & $\begin{array}{c}1.326 \\
(2.403)\end{array}$ & $\begin{array}{c}15.501^{* * * *} \\
(2.701)\end{array}$ & -21.927 & $0.217 /(206)$ \\
\hline $45-49$ & $\begin{array}{c}0.235^{*} \\
(0.012)\end{array}$ & $\begin{array}{c}-0.036 \\
(0.102)\end{array}$ & $\begin{array}{r}-0.078 \\
(0.235)\end{array}$ & $\begin{array}{c}-0.040 \\
(0.021)\end{array}$ & $\begin{array}{c}-0.617 \\
(0.547)\end{array}$ & $\begin{array}{r}-1.641^{*} \\
(0.711)\end{array}$ & $\begin{array}{c}0.043 \\
(2.132)\end{array}$ & $\begin{array}{c}12.233 * * * \\
(2.397)\end{array}$ & -11.845 & $0.182 /(206)$ \\
\hline $50-59$ & $\begin{array}{c}0.139 \\
(0.077)\end{array}$ & $\begin{array}{c}-0.088 \\
(0.077)\end{array}$ & $\begin{array}{c}-0.039 \\
(0.178)\end{array}$ & $\begin{array}{c}-0.012 \\
(0.016)\end{array}$ & $\begin{array}{c}-0.416 \\
(0.414)\end{array}$ & $\begin{array}{r}-1.299 * \\
(0.539)\end{array}$ & $\begin{array}{c}-0.120 \\
(1.614)\end{array}$ & $\begin{array}{l}9.713^{* * *} \\
(1.814)\end{array}$ & -0.558 & $0.166 /(206)$ \\
\hline $60-69$ & $\begin{array}{c}-0.059 \\
(0.111)\end{array}$ & $\begin{array}{r}-0.263^{*} \\
(0.110)\end{array}$ & $\begin{array}{c}-0.360 \\
(0.255)\end{array}$ & $\begin{array}{c}0.024 \\
(0.023)\end{array}$ & $\begin{array}{c}0.330 \\
(0.592)\end{array}$ & $\begin{array}{r}-1.398 \\
(0.770)\end{array}$ & $\begin{array}{c}2.025 \\
(2.306)\end{array}$ & $\begin{array}{l}15.563^{* * *} \\
(2.593)\end{array}$ & 30.859 & $0.227 /(206)$ \\
\hline $70+$ & $\begin{array}{c}0.081 \\
(0.115)\end{array}$ & $\begin{array}{r}-0.407 * * * \\
(0.114)\end{array}$ & $\begin{array}{r}-0.792 * * \\
(0.264)\end{array}$ & $\begin{array}{c}0.040 \\
(0.024)\end{array}$ & $\begin{array}{c}0.338 \\
(0.614)\end{array}$ & $\begin{array}{c}-0.964 \\
(0.798)\end{array}$ & $\begin{array}{c}4.465 \\
(2.392)\end{array}$ & $\begin{array}{c}19.790 * * * \\
(2.688)\end{array}$ & 35.584 & $0.357 /(206)$ \\
\hline
\end{tabular}




\begin{tabular}{|c|c|c|c|c|c|c|c|c|c|c|}
\hline $\begin{array}{c}\text { AGE } \\
\text { GROUP }\end{array}$ & PROFM70+ & $\mathrm{LABM} 70+$ & CLERF70+ & TAX67 & UNRT60 & UNRT70 & SOUTH & WEST & Const. & $\mathrm{R}^{2} /(\mathrm{N})$ \\
\hline \multicolumn{11}{|c|}{ Black Males } \\
\hline $25-29$ & $\begin{array}{l}1.213^{* *} \\
(0.441)\end{array}$ & $\begin{array}{c}0.330 \\
(0.480)\end{array}$ & $\begin{array}{l}2.299 * \\
(1.121)\end{array}$ & $\begin{array}{c}0.051 \\
(0.092)\end{array}$ & $\begin{array}{c}-9.224 * * * \\
(2.735)\end{array}$ & $\begin{array}{c}6.569 * \\
(3.282)\end{array}$ & $\begin{array}{c}-26.082 * * \\
(9.620)\end{array}$ & $\begin{array}{c}2.052 \\
(12.434)\end{array}$ & -196.109 & $0.525 /(167)$ \\
\hline $30-34$ & $\begin{array}{c}0.781 * \\
(0.320)\end{array}$ & $\begin{array}{c}0.353 \\
(0.344)\end{array}$ & $\begin{array}{l}2.420 * * \\
(0.806)\end{array}$ & $\begin{array}{c}0.074 \\
(0.066)\end{array}$ & $\begin{array}{c}-2.244 \\
(2.044)\end{array}$ & $\begin{array}{c}-0.797 \\
(2.390)\end{array}$ & $\begin{array}{c}-18.996 * * \\
(6.944)\end{array}$ & $\begin{array}{c}-23.187 * * \\
(8.796)\end{array}$ & -174.972 & $0.520 /(169)$ \\
\hline $35-39$ & $\begin{array}{c}0.177 \\
(0.225)\end{array}$ & $\begin{array}{l}0.219 \\
(0.244)\end{array}$ & $\begin{array}{l}1.886 * * * \\
(0.566)\end{array}$ & $\begin{array}{c}0.007 \\
(0.047)\end{array}$ & $\begin{array}{r}-3.240^{*} \\
(1.449)\end{array}$ & $\begin{array}{c}0.546 \\
(1.695)\end{array}$ & $\begin{array}{c}-9.939 \\
(4.925)\end{array}$ & $\begin{array}{c}-3.586 \\
(6.183)\end{array}$ & -87.847 & $0.361 /(165)$ \\
\hline $40-44$ & $\begin{array}{c}0.178 \\
(0.165)\end{array}$ & $\begin{array}{l}0.623 * * * \\
(0.177)\end{array}$ & $\begin{array}{c}0.510 \\
(0.417)\end{array}$ & $\begin{array}{c}-0.061 \\
(0.034)\end{array}$ & $\begin{array}{r}-2.529 * \\
(1.068)\end{array}$ & $\begin{array}{c}-0.227 \\
(1.232)\end{array}$ & $\begin{array}{r}-1.531 \\
(3.655)\end{array}$ & $\begin{array}{c}12.426 * * \\
(4.686)\end{array}$ & -47.037 & $0.329 /(163)$ \\
\hline $45-49$ & $\begin{array}{c}0.419 * \\
(0.165)\end{array}$ & $\begin{array}{c}-0.037 \\
(0.181)\end{array}$ & $\begin{array}{c}-0.182 \\
(0.422)\end{array}$ & $\begin{array}{r}-0.014 \\
(0.034)\end{array}$ & $\begin{array}{r}-1.480 \\
(1.091)\end{array}$ & $\begin{array}{c}0.136 \\
(0.246)\end{array}$ & $\begin{array}{c}-10.472 * * \\
(3.702)\end{array}$ & $\begin{array}{c}-0.327 \\
(4.518)\end{array}$ & -19.337 & $0.238 /(163)$ \\
\hline $50-59$ & $\begin{array}{l}-0.017 \\
(0.159)\end{array}$ & $\begin{array}{c}0.228 \\
(0.174)\end{array}$ & $\begin{array}{c}0.438 \\
(0.404)\end{array}$ & $\begin{array}{c}0.014 \\
(0.033)\end{array}$ & $\begin{array}{c}-2.484 * * \\
(0.981)\end{array}$ & $\begin{array}{c}-0.146 \\
(1.180)\end{array}$ & $\begin{array}{c}-1.939 \\
(3.404)\end{array}$ & $\begin{array}{c}3.797 \\
(4.319)\end{array}$ & -12.361 & $0.137 /(172)$ \\
\hline $60-69$ & $\begin{array}{c}0.176 \\
(0.151)\end{array}$ & $\begin{array}{c}-0.175 \\
(0.165)\end{array}$ & $\begin{array}{c}-0.251 \\
(0.388)\end{array}$ & $\begin{array}{r}-0.005 \\
(0.032)\end{array}$ & $\begin{array}{r}-1.616 \\
(0.944)\end{array}$ & $\begin{array}{c}1.683 \\
(1.129)\end{array}$ & $\begin{array}{c}-5.349 \\
(3.273)\end{array}$ & $\begin{array}{c}3.190 \\
(4.256)\end{array}$ & 4.600 & $0.054 /(169)$ \\
\hline $70+$ & $\begin{array}{c}-0.024 \\
(0.179)\end{array}$ & $\begin{array}{c}-0.257 \\
(0.207)\end{array}$ & $\begin{array}{l}0.503 \\
(0.465)\end{array}$ & $\begin{array}{c}0.100 * \\
(0.040)\end{array}$ & $\begin{array}{l}1.169 \\
(1.255)\end{array}$ & $\begin{array}{c}0.195 \\
(1.470)\end{array}$ & $\begin{array}{c}0.517 \\
(4.010)\end{array}$ & $\begin{array}{l}9.379 \\
(5.378)\end{array}$ & -22.393 & $0.142 /(152)$ \\
\hline
\end{tabular}

NOTE: *indicates significant at the .05 level

**indicates significant at the .01 level

***indicates significant at the .001 level

+indicates coefficients and standard errors for this variable are 100 times their actual values 
and income streams both at home and in locations B and C. The person may decide to move and/or "invest" more in himself (school, training, etc.), or to stay put. Since younger persons have more working years ahead of them in which to collect an income stream and recoup early losses, it is reasonable for them to go to college, clerical school, and so forth. More highly "capitalized" persons will move, just like physical capital, to the region of greatest return.

The relationship can be expressed as:

$$
\mathrm{M}_{\mathrm{ik}}=f\left(\int_{\mathrm{t}=0}^{\mathrm{T}}\left(\mathrm{Y}_{\mathrm{kt}}-\mathrm{Y}_{\mathrm{it}}\right) e^{-\mathrm{rt}} d t-c_{\mathrm{ik}}\right)
$$

$\mathrm{M}_{\mathrm{ik}}$ is migration rate from $i$ to $k$

$t=0$ is present time

$\mathrm{T}$ is retirement time

$\mathrm{Y}_{\mathrm{kt}}$ is yearly income at the potential destination

$\mathrm{Y}_{\mathrm{ik}}$ is yearly income at the present location

$r$ is the discount rate

$c_{\mathrm{ik}} \quad$ is the total (fixed) cost of moving from $i$ to $k$

$e \quad$ is the base of the natural logarithm.

Since the data used here is for net migration, the difference in pairs of SMSA income levels and associated living and moving costs cannot be entered into the regression equations. This presents no great problem; one can just reformulate the model as:

$$
\mathrm{M}_{\mathrm{ij}}=f\left(\int_{\mathrm{t}=0}^{\mathrm{T}} \mathrm{Y}_{\mathrm{i}}^{*} e^{-\mathrm{rt}} d t-c_{\mathrm{i}}\right)
$$

$\mathrm{M}_{\mathrm{ij}}$ is the net migration rate of the $j$ th age-race group to SMSA $i$

$\mathrm{Y}_{\mathrm{i}}^{*}$ is the income level of SMSA $i$

$c_{\mathrm{i}} \quad$ is the sum of (one-time) costs that accrue to a resident moving to SMSA $i$

To be proper, local money income deflated by real costs of living should be used for income in the equation. On the cost side, one may include out-of-pocket expenses in moving, "psychic costs" of being away from family and friends, and "search costs" for new jobs, housing, and the like. Costs that are a one-time affair (like moving expenses) matter little if expected lifetime is long; they are quickly outweighed by any gains to personal income.

A number of empirically testable hypotheses derive from this theory. The propensity to migrate would be expected to decline with age itself; that is, the present discounted value of income differences among cities is expected to have the greatest effect on younger migrants. For an individual aged 25 at present, a constant $\$ 1,000.00$ difference in income between cities $\mathrm{A}$ and $\mathrm{B}$ over his working lifetime amounts to a total discounted difference of about $\$ 14,700$, using $r=.06$. For a worker aged 
55 , the difference is only $\$ 7,300$. Although not measured here, greater migration would also be expected among the more highly educated or more highly trained (due to a geographically more extensive job market), but less migration the greater the distance (cost) involved and from those with more dependents.

Schwartz [11] has found empirical support for this theory. He shows that the migration rate is higher at every age for those with higher educational attainment; it declines with age for each educational level; and the decline is steeper for the more highly educated, all in accordance with his predictions. Bowles [2] found the human capital approach useful in explaining migration out of the American South by age, race, and education. The theory's strength comes as no surprise; while never so explicitly formulated, the theory of human capital underlies much previous work on migration, and is corroborated in its findings.

Some caution is necessary, however. First, as Greenwood has pointed out, in cases where regional incomes are growing at different rates and migrants take this into account, current aggregate earnings will not properly measure discounted values of income streams (6, p. 399). Second, it is not even clear that individuals are at all consistent (even by broad age, race, and sex groups) in the discount rate that they employ. Current research uses of the discount rate usually amount to an educated guess based on the prevailing rate for physical capital.

The model under consideration is now:

$$
\begin{aligned}
& \mathrm{M}_{\mathrm{ij}}=f\left(\mathrm{Y}_{\mathrm{ik}}, t_{\mathrm{i}}, \mathrm{u}_{\mathrm{i}}, r\right) \\
& \mathrm{M}_{\mathrm{ij}}=\text { migration rate for } j \text { th age-race group to SMSA } i \\
& \mathrm{Y}_{\mathrm{ik}}=\text { wage rate of the } k \text { th occupational group in SMSA } i \\
& t_{\mathrm{i}}=\text { the tax rate in SMSA } i \\
& \mathrm{u}_{\mathrm{i}}=\text { unemployment rate(s) in SMSA } i \\
& r \quad=\text { regional effects represented by dummy variables. }
\end{aligned}
$$

Specific independent variables (using the mnemonics as in the regression tables) used to test this model are:

PROFM70, LABM70, CLERF70-Median yearly earnings of professional workers (male), laborers (male), and clerical workers (female) in 1970, respectively;

UNRT60, UNRT70_SMSA unemployment rate 1960 and 1970, respectively;

TAX67-Average per capita property taxes for SMSA 1970;

$\mathrm{S}$-equals 1 if SMSA is South Census Region, 0 otherwise;

W-equals 1 if SMSA in West Census Region, 0 otherwise.

Under the assumptions of the model one would expect that the three earnings variables would show positive effects $\left(\partial \mathrm{M}_{\mathrm{ij}} / \partial \mathrm{Y}_{\mathrm{ik}}>0\right)$ on migration. 
It can be hypothesized that more highly trained occupations exhibit the most migration. Even though there are no occupation-specific migration rates, one would expect to find that higher local earnings in professional occupations (geographically extensive job search) would tend to attract comparatively more migrants, that is,

$$
\partial \mathrm{M}_{\mathrm{ij}} / \partial \mathrm{Y}_{\mathrm{i} 1}>\partial \mathrm{m}_{\mathrm{ij}} / \partial \mathrm{Y}_{\mathrm{i} 2}>\ldots>0 \quad \text { as } \mathrm{Y}_{\mathrm{i} 1}>\mathrm{Y}_{\mathrm{i} 2}>\ldots>\mathrm{Y}_{\mathrm{in}}
$$

Moreover, the effect of the income variable should decline as the age group of migrants increases since there are less present discounted returns to migration (i.e.,

$$
\left.\frac{\partial}{\partial_{\mathrm{j}}}\left(\partial \mathrm{M}_{\mathrm{ij}} / \partial \mathrm{Y}_{\mathrm{ik}}\right)<0\right)
$$

where $j$ increases with age.

The coefficients of both unemployment variables should be negative $\left(\partial \mathrm{M}_{\mathrm{ij}} / \partial \mathrm{u}_{\mathrm{i}}<0\right)$ but it is difficult to predict which end of the decade should be stronger. If a time lag occurs between economic factors which precipitate a move and the actual move, the 1960 rates will be of greater magnitude. However, since 1970 figures are more proximate to recent migration (and these ten-year rates are biased toward the end of the decade since many intervening moves occurred and are not measured), their coefficients may be stronger. If the unemployment rate does serve as a shadow for employment opportunities, we might expect it to operate most strongly on entrants to the labor force who have less experience and tenure.

Several versions of this economic model were actually tested. These included equations both with and without the South and West dummies to ascertain the strength of residual regional effects. In some equations a single income variable (per capita SMSA income, 1970) was used in place of the three separate measures. The model was run without any unemployment variables, as well as with the three unemployment versions mentioned above. The results obtained from these other equations did not differ substantively from those presented in Table 1, which is the most inclusive model.

Results. The regression results generally support this economic model. Professional earnings are consistently the strongest predictor of the migration rate to a given SMSA. Its effect is more pronounced for whites who have more access to the professional labor market. A $\$ 1,000$ increase in PROFM70 predicts a 12-point rise in a city's net migration rate for white males ages 25-29. As hypothesized by human capital theory, the strongest effects are found in the younger age groups (both black and white) whose members have the most to gain in lifetime earnings by moving. Younger cohorts also contain higher proportions of more highly educated and specially trained job seekers. The negative coefficient for LABM70 for several white age groups is noteworthy: the higher the city's wage rate for laborers the greater its population loss. While this is undoubtedly due to aggregation over all occupations in the migration rate, it does suggest that 
(among the youngest and oldest age groups particularly) the kinds of conditions that accompany these high wages are disagreeable in some respect. High wages in certain cities may reflect compensation for living in - a disagreeable locality. Rising incomes would lead to outmigration, i.e. substitution away from that inferior bundle.

Taxes were generally not significant. Interestingly, though, the direction of its effect for middle-aged whites is negative (and significant at .05), perhaps indicating that many individuals in this category perceive that they are not getting their money's worth in some highly taxed metropolitan areas. It appears also that TAX67 is so correlated with other independent variables that it may be explained away by their entry into the equation. ${ }^{4}$

The inclusion of both UNRT60 and UNRT70 in the equation caused a statistically significant increase in $\mathrm{R}^{2}$. The added variables are generally more important for whites than blacks. For total white males (equation not shown), the increase in $\mathrm{R}^{2}$ was on the order of 40 percent $(a<.001)$. This figure increased throughout the principal labor force ages. For total black males there was an increase of only about 6.5 percent $(a<.025)$ in the variance explained, and no age-specific pattern emerged. The effects of change in the unemployment rate were not as strong as the effects of absolute level, and were made insignificant upon correction for region. The variable's effects operate in the expected direction. UNRT60 is especially significant for the 25-29 year olds who entered the labor force en masse during the decade. The effect of unemployment declines with maturation of the cohorts, presumably as older workers have more stable positions and are less affected by the local unemployment rate. For no immediately obvious reason, the 1960 rate operates more strongly on blacks, while whites tend to respond to the 1970 rate. In the age groups in which individuals begin to retire, the impact of unemployment rate is no longer significant.

Despite the predictive power of the several economic variables in the equation, residual regional effects remain. The pair of dummy variables contributes to most of the equations in a way that is statistically significant. After basic economic effects are accounted for there is still heavy white migration toward the West (and moderately toward the South), while for blacks there is moderately strong movement out of the South (especially in the youngest ages) and inconsistent movement with regard to the West across the several age groups.

The model suggests the value of the human capital approach to migration research, and shows the necessity of accounting for the availability of employment in regions in addition to prevailing wage rates. For whites the adjusted $\mathrm{R}^{2}$ is highest $(0.461)$ at ages $25-29$, and then declines steadily throughout the main labor force ages, with a slight rise toward retirement. For blacks a similar pattern emerges: the proportion of variance explained at each age is higher than for whites, but declines with age without any corresponding increase in the model's ability to predict the mobility of the two oldest groups. 


\section{THE DEMAND FOR NON-TRADED GOODS: MODEL II}

That individuals migrate for reasons other than mere pecuniary gain has long been evident. Along with money income, people seek by moving to gain better climates, public services, educational facilities, etc. One might expect that as incomes rise and the majority of basic needs are met these other goods assume a more important role in the distribution of population. One set of goods is of particular relevence here. They are location specific or non-traded, and different "packages" of them cannot be purchased in the local market. Only a physical move allows a different level of consumption. Outdoor tennis is impossible year-round in Minneapolis; a snowmobile is useless in San Antonio.

In the economic analysis of the consumer, an individual is said to be in equilibrium when, for each good, $\mathrm{MU}_{\mathrm{i}} / \mathrm{P}_{\mathrm{i}}$ are equal $\left(\mathrm{MU}_{\mathrm{i}}\right.$ is the marginal utility of the good, and $P_{\mathrm{i}}$ is its price). Equivalently, equilibrium exists when the ratio of marginal utilities of any pair of goods is equal to the ratio of their prices. For goods consumed in the traditional marketplace, the concept is straightforward. For non-traded goods, the marginal utilities and disutilities are compensated by losses and gains to wages, respectively. When the loss in wages at a (new) locality plus the other costs is less than the benefits gained, the theory predicts migration to that place. One may be willing to trade off a little money income for the opportunity to increase utility along another dimension, thereby remaining in consumer's equilibrium. In this sense these non-traded goods are no different from other goods. Just as some workers will accept a lower salary to be able to play golf year round, some employers will have to offer higher wages if their plant or office is in a smoggy location.

Formally, one can write the household's utility function as:

$$
\mathrm{U}=\mathrm{u}\left(\mathrm{X}_{1}, \ldots, \mathrm{X}_{\mathrm{m}} ; \mathrm{E}_{1}, \ldots, \mathrm{E}_{\mathrm{n}} ; \mathrm{F}_{1}, \ldots, \mathrm{F}_{\mathrm{k}}\right)
$$

where $\mathrm{X}_{\mathrm{i}}$ represent purchased private commodities, $\mathrm{E}_{\mathrm{j}}$ represent public goods, and $F_{k}$ represent non-traded goods. In circumstances where (at least for a particular demographic group) $\mathrm{U}_{\mathrm{i}}<\mathrm{U}_{\mathrm{j}}$ we expect migration from $i$ to $j$. Here $\mathrm{U}$ is total utility, from $\mathrm{X}_{\mathrm{i}}, \mathrm{E}_{\mathrm{j}}, \mathrm{F}_{\mathrm{k}}$, and subscripts refer to alternative locations $i$ and $j$. In cases where a city can offer greater consumption of non-tradeable goods (other things being equal), we expect inmigration, i.e., $\partial \mathrm{M}_{\mathrm{ij}} / \partial \mathrm{F}_{\mathrm{k}}>0$ for $\mathrm{F}$ positively valued by consumers. The following is a list of variables used here to measure the effect of non-traded goods. INC70 is included as a necessary benchmark against which to measure the others. SS70, EDUC67, JAN, and AFDC70 are all expected to have positive coefficients; the opposite is true for the remaining four:

INC70 income in 1970 per capita for the SMSA;

AFDC70 per capita aid to families with dependent children; 
EDUC67 percent of local revenues expended on education;
JAN January mean temperature;
JULY
July mean temperature;
AGE number of years (cenuses) since the central city popula- tion reached 50,000, an indicator of deteriorating public and private facilities, housing stock, etc.;
CRIMAVE simple average of the (FBI) 1961 and 1972 metropolitan crime indices;

LDGENS natural logarithm of SMSA population density.

Not all moves to gain utility by increased consumption of these goods need by intermetropolitan. Inasmuch as a Tiebout economy operates locally, density, crime, and educational expenditures may not significantly affect interregional population redistribution.

In other empirical work, Cebula [3] found some significant effects of pollution, sunshine, temperature, welfare payments, and the availability of physicians on interregional moves. In an extensive analysis of climatic variables alone, Graves [5] was able to find some statistically significant effects for temperature, wind, and humidity.

Local amenities spur inmigration in two ways: (1) they attract migrants because of the outright increase in their utility, and (2) they attract new business and industry because management can pay workers less, since they are willing to give up a little of their weekly wages to live in a more pleasant locale. Such migration of industry induces further movement of population. Hence the phenomenal movement of both persons and industry to the sunbelt.

Results. An examination of Table 2 shows that the effects of these nontraded goods are not especially strong. Even with the eleven variables in the equation, adjusted $\mathrm{R}^{2}$ values often range below 15 percent. For the most part, the predicted patterns hold. More of the variation for the black population can be explained because of the impact of AFDC payments. For younger blacks the effect of AFDC payments was especially strong and positive, but for whites the effect was weak and operated in the opposite direction. This is likely due to the fact that a larger proportion of the black population is eligible for welfare, and high welfare payments represent no direct benefits, some higher taxes, and perceived indirect losses to many middle class whites. Social security payments exhibited no meaningful pattern.

Educational expenditures, crime, and density produced no significant influences in the predicted directions, which accords with the presence of local Tiebout economies for these goods. (Positive effects of density and crime in the younger ages may actually be measuring employment opportunities in larger cities.) Whites are moving to SMSAs with younger central cities, and blacks to older SMSAs, indicating a fundamental demographic shift that has been extensively documented. The regression results show 
TABLE 2. Model II-The Demand for Non-Traded Goods

\begin{tabular}{|c|c|c|c|c|c|c|c|c|c|c|c|c|c|}
\hline $\begin{array}{l}\text { AGE } \\
\text { GROL'P }\end{array}$ & INC70+ & SS70 & AFDC70 & EDLC67 & JAN & JULY & CCACiF & LGDENS & CRIMAVE & $\mathrm{s}$ & $w^{\prime}$ & Const. & $\mathrm{R}^{2} /(\mathrm{N})$ \\
\hline \multicolumn{14}{|c|}{ White Males } \\
\hline $25-29$ & $\begin{array}{l}1.881 * * * \\
(0.520)\end{array}$ & $\begin{array}{c}-0.040 \\
(0.283)\end{array}$ & $\begin{array}{r}-0.098^{*} \\
(0.046)\end{array}$ & $\begin{array}{c}0.047 \\
(0.220)\end{array}$ & $\begin{array}{c}-0.490 \\
(0.251)\end{array}$ & $\begin{array}{c}-0.219 \\
(0.504)\end{array}$ & $\begin{array}{c}-0.083 \\
(0.609)\end{array}$ & $\begin{array}{c}5.613 \\
(2.589)\end{array}$ & $\begin{array}{l}0.009 * * \\
(0.003)\end{array}$ & $\begin{array}{l}10.207 \\
(6.891)\end{array}$ & $\begin{array}{c}14.450 \\
(7.286)\end{array}$ & -50.301 & $0.240 /(206)$ \\
\hline $30-34$ & $\begin{array}{l}1.706^{* * *} \\
(0.594)\end{array}$ & $\begin{array}{c}0.485 \\
(0.324)\end{array}$ & $\begin{array}{c}-0.066 \\
(0.053)\end{array}$ & $\begin{array}{r}-0.131 \\
(0.252)\end{array}$ & $\begin{array}{c}-0.226 \\
(0.287)\end{array}$ & $\begin{array}{c}0.204 \\
(0.577)\end{array}$ & $\begin{array}{c}0.062 \\
(0.070)\end{array}$ & $\begin{array}{l}1.610 \\
(2.961)\end{array}$ & $\begin{array}{c}-0.003 \\
(0.003)\end{array}$ & $\begin{array}{c}6.551 \\
(7.882)\end{array}$ & $\begin{array}{r}18.375^{*} \\
(8.333)\end{array}$ & -116.022 & $0.139 /(206)$ \\
\hline $35-39$ & $\begin{array}{c}0.499 \\
(0.333)\end{array}$ & $\begin{array}{c}-0.071 \\
(0.181)\end{array}$ & $\begin{array}{c}-0.021 \\
(0.029)\end{array}$ & $\begin{array}{r}-0.095 \\
(0.041)\end{array}$ & $\begin{array}{c}0.026 \\
(0.161)\end{array}$ & $\begin{array}{c}-0.407 \\
(0.323)\end{array}$ & $\begin{array}{c}-0.001 \\
(0.039)\end{array}$ & $\begin{array}{c}1.982 \\
(1.658)\end{array}$ & $\begin{array}{c}0.000 \\
(0.002)\end{array}$ & $\begin{array}{c}3.222 \\
(4.413)\end{array}$ & $\begin{array}{l}12.803 * * \\
(4.665)\end{array}$ & 9.599 & $0.096 /(206)$ \\
\hline $40-44$ & $\begin{array}{c}0.067 \\
(0.002)\end{array}$ & $\begin{array}{c}-0.003 \\
(0.135)\end{array}$ & $\begin{array}{c}-0.026 \\
(0.022)\end{array}$ & $\begin{array}{r}-0.090 \\
(0.105)\end{array}$ & $\begin{array}{c}0.124 \\
(0.119)\end{array}$ & $\begin{array}{c}-0.458 \\
(0.240)\end{array}$ & $\begin{array}{c}-0.282 \\
(0.029)\end{array}$ & $\begin{array}{c}1.383 \\
(1.231)\end{array}$ & $\begin{array}{c}0.002 \\
(0.001)\end{array}$ & $\begin{array}{r}-0.640 \\
(3.276)\end{array}$ & $\begin{array}{c}6.385 \\
(3.463)\end{array}$ & 27.377 & $0.115 /(206)$ \\
\hline $45-49$ & $\begin{array}{c}-0.001 \\
(0.216)\end{array}$ & $\begin{array}{c}0.043 \\
(0.118)\end{array}$ & $\begin{array}{c}-0.028 \\
(0.019)\end{array}$ & $\begin{array}{c}-0.094 \\
(0.092)\end{array}$ & $\begin{array}{l}0.120 \\
(0.104)\end{array}$ & $\begin{array}{c}-0.416 \\
(0.210)\end{array}$ & $\begin{array}{c}-0.036 \\
(0.025)\end{array}$ & $\begin{array}{l}1.411 \\
(1.076)\end{array}$ & $\begin{array}{l}0.002 \\
(0.001)\end{array}$ & $\begin{array}{r}-1.325 \\
(2.865)\end{array}$ & $\begin{array}{l}4.175 \\
(3.029)\end{array}$ & 22.306 & $0.098 /(206)$ \\
\hline $50-59$ & $\begin{array}{c}-0.013 \\
(0.002)\end{array}$ & $\begin{array}{c}0.065 \\
(0.087)\end{array}$ & $\begin{array}{r}-0.018 \\
(0.014)\end{array}$ & $\begin{array}{c}-0.077 \\
(0.068)\end{array}$ & $\begin{array}{c}0.185^{*} \\
(0.077)\end{array}$ & $\begin{array}{r}-0.312 * \\
(0.155)\end{array}$ & $\begin{array}{c}-0.033 \\
(0.019)\end{array}$ & $\begin{array}{c}0.282 \\
(0.794)\end{array}$ & $\begin{array}{l}0.002 \\
(0.001)\end{array}$ & $\begin{array}{r}-2.313 \\
(2.114)\end{array}$ & $\begin{array}{l}1.844 \\
(2.235)\end{array}$ & 14.190 & $0.129 /(206)$ \\
\hline $60-69$ & $\begin{array}{r}-0.410 * \\
(0.209)\end{array}$ & $\begin{array}{c}0.149 \\
(0.114)\end{array}$ & $\begin{array}{c}-0.002 \\
(0.018)\end{array}$ & $\begin{array}{r}-0.193 * \\
(0.089)\end{array}$ & $\begin{array}{l}0.487 * * * \\
(0.101)\end{array}$ & $\begin{array}{c}0.551 \\
(0.203)\end{array}$ & $\begin{array}{r}-0.054 * \\
(0.025)\end{array}$ & $\begin{array}{c}-1.272 \\
(1.042)\end{array}$ & $\begin{array}{c}0.000 \\
(0.001)\end{array}$ & $\begin{array}{r}-4.605 \\
(2.775)\end{array}$ & $\begin{array}{l}4.280 \\
(2.933)\end{array}$ & -3.994 & $0.31 \tilde{5} /(206)$ \\
\hline $70+$ & $\begin{array}{c}-0.004 \\
(0.002)\end{array}$ & $\begin{array}{c}0.216 \\
(0.118)\end{array}$ & $\begin{array}{c}0.005 \\
(0.019)\end{array}$ & $\begin{array}{r}-0.145 \\
(0.091)\end{array}$ & $\begin{array}{l}0.510 * * * \\
(0.104)\end{array}$ & $\begin{array}{c}0.175 \\
(0.209)\end{array}$ & $\begin{array}{c}-0.087 * * * \\
(0.025)\end{array}$ & $\begin{array}{c}-1.890 \\
(1.075)\end{array}$ & $\begin{array}{l}0.001 \\
(0.001)\end{array}$ & $\begin{array}{c}-2.626 \\
(2.863)\end{array}$ & $\begin{array}{l}8.306 * * \\
(3.026)\end{array}$ & -26.445 & $0.437 /(2() 6)$ \\
\hline
\end{tabular}


TABLE 2. Model II-The Demand for Non-Traded Goods (Cont.)

\begin{tabular}{|c|c|c|c|c|c|c|c|c|c|c|c|c|c|}
\hline $\begin{array}{l}\text { AGE } \\
\text { GROUP }\end{array}$ & INC70+ & SS70 & AFDC70 & EDUC67 & JAN & JULY & CCAGE & LGDENS & CRIMAVE & S & w & Const. & $\mathrm{R}^{2 /(\mathrm{N})}$ \\
\hline \multicolumn{14}{|c|}{ Black Males } \\
\hline $25-29$ & $\begin{array}{c}2.562 * \\
(1.017)\end{array}$ & $\begin{array}{l}0.102 \\
(0.516)\end{array}$ & $\begin{array}{l}0.116 \\
(0.087)\end{array}$ & $\begin{array}{c}0.728 \\
(0.425)\end{array}$ & $\begin{array}{c}-0.307 \\
(0.508)\end{array}$ & $\begin{array}{c}-0.921 \\
(0.986)\end{array}$ & $\begin{array}{c}-0.008 \\
(0.114)\end{array}$ & $\begin{array}{r}11.844^{*} \\
(5.387)\end{array}$ & $\begin{array}{c}0.005 \\
(0.006)\end{array}$ & $\begin{array}{r}-10.743 \\
(12.536)\end{array}$ & $\begin{array}{c}28.851 \\
(16.998)\end{array}$ & -133.340 & $0.479 /(167)$ \\
\hline $30-34$ & $\begin{array}{c}1.746 * \\
(0.727)\end{array}$ & $\begin{array}{r}0.065 \\
(0.360)\end{array}$ & $\begin{array}{c}0.195 * * \\
(0.060)\end{array}$ & $\begin{array}{c}0.571 \\
(0.297)\end{array}$ & $\begin{array}{c}0.038 \\
(0.352)\end{array}$ & $\begin{array}{c}-0.335 \\
(0.680)\end{array}$ & $\begin{array}{l}0.216^{* *} \\
(0.080)\end{array}$ & $\begin{array}{c}0.296 \\
(3.736)\end{array}$ & $\begin{array}{c}0.007 * \\
(0.004)\end{array}$ & $\begin{array}{r}-8.584 \\
(8.766)\end{array}$ & $\begin{array}{l}-21.869 \\
(11.633)\end{array}$ & -121.326 & $0.512 /(169)$ \\
\hline $35-39$ & $\begin{array}{c}0.724 \\
(0.494)\end{array}$ & $\begin{array}{c}-0.423 \\
(0.244)\end{array}$ & $\begin{array}{l}0.197 * * * \\
(0.041)\end{array}$ & $\begin{array}{c}0.357 \\
(0.209)\end{array}$ & $\begin{array}{c}0.310 \\
(0.240)\end{array}$ & $\begin{array}{c}-0.112 \\
(0.460)\end{array}$ & $\begin{array}{l}0.170 * * \\
(0.054)\end{array}$ & $\begin{array}{c}-0.325 \\
(2.550)\end{array}$ & $\begin{array}{c}0.003 \\
(0.003)\end{array}$ & $\begin{array}{c}-6.745 \\
(5.941)\end{array}$ & $\begin{array}{c}-10.424 \\
(7.858)\end{array}$ & -31.637 & $0.399 /(165)$ \\
\hline $40-44$ & $\begin{array}{c}0.066 \\
(0.388)\end{array}$ & $\begin{array}{c}-0.131 \\
(0.190)\end{array}$ & $\begin{array}{c}0.064 * \\
(0.033)\end{array}$ & $\begin{array}{c}0.243 \\
(0.165)\end{array}$ & $\begin{array}{c}0.063 \\
(0.194)\end{array}$ & $\begin{array}{c}0.111 \\
(0.364)\end{array}$ & $\begin{array}{c}0.103 * \\
(0.043)\end{array}$ & $\begin{array}{c}3.254 \\
(1.993)\end{array}$ & $\begin{array}{c}-0.003 \\
(0.002)\end{array}$ & $\begin{array}{r}-4.048 \\
(4.719)\end{array}$ & $\begin{array}{l}15.317 * \\
(6.433)\end{array}$ & -35.648 & $0.270 /(163)$ \\
\hline $45-49$ & $\begin{array}{c}-0.149 \\
(0.380)\end{array}$ & $\begin{array}{c}0.172 \\
(0.191)\end{array}$ & $\begin{array}{c}0.015 \\
(0.033)\end{array}$ & $\begin{array}{c}-0.094 \\
(0.160)\end{array}$ & $\begin{array}{c}-0.013 \\
(0.189)\end{array}$ & $\begin{array}{c}-0.330 \\
(0.354)\end{array}$ & $\begin{array}{c}0.042 \\
(0.042)\end{array}$ & $\begin{array}{c}0.031 \\
(1.914)\end{array}$ & $\begin{array}{c}0.000 \\
(0.002)\end{array}$ & $\begin{array}{c}-6.370 \\
(4.778)\end{array}$ & $\begin{array}{l}-0.622 \\
(5.852)\end{array}$ & 13.109 & $0.187 /(163)$ \\
\hline $50-59$ & $\begin{array}{c}-0.280 \\
(0.364)\end{array}$ & $\begin{array}{c}0.136 \\
(0.180)\end{array}$ & $\begin{array}{c}0.040 \\
(0.030)\end{array}$ & $\begin{array}{c}-0.076 \\
(0.151)\end{array}$ & $\begin{array}{c}0.197 \\
(0.172)\end{array}$ & $\begin{array}{c}0.491 \\
(0.344)\end{array}$ & $\begin{array}{c}0.027 \\
(0.040)\end{array}$ & $\begin{array}{c}3.031 \\
(1.846)\end{array}$ & $\begin{array}{r}-0.000 \\
(0.002)\end{array}$ & $\begin{array}{c}-6.522 \\
(4.272)\end{array}$ & $\begin{array}{r}3.728 \\
(5.531)\end{array}$ & -69.278 & $0.097 /(172)$ \\
\hline $60-69$ & $\begin{array}{c}-0.616 \\
(0.337)\end{array}$ & $\begin{array}{c}0.077 \\
(0.170)\end{array}$ & $\begin{array}{c}-0.001 \\
(0.028)\end{array}$ & $\begin{array}{c}0.025 \\
(0.041)\end{array}$ & $\begin{array}{c}-0.152 \\
(0.168)\end{array}$ & $\begin{array}{c}0.859 * * \\
(0.327)\end{array}$ & $\begin{array}{c}-0.006 \\
(0.037)\end{array}$ & $\begin{array}{c}4.071^{*} \\
(1.768)\end{array}$ & $\begin{array}{c}-0.001 \\
(0.002)\end{array}$ & $\begin{array}{c}-5.670 \\
(4.078)\end{array}$ & $\begin{array}{l}14.411 * * \\
(5.484)\end{array}$ & -69.376 & $0.063 /(169)$ \\
\hline $70+$ & $\begin{array}{c}-0.506 \\
(0.436)\end{array}$ & $\begin{array}{c}0.245 \\
(0.195)\end{array}$ & $\begin{array}{c}0.052 \\
(0.034)\end{array}$ & $\begin{array}{c}0.031 \\
(0.172)\end{array}$ & $\begin{array}{c}0.032 \\
(0.206)\end{array}$ & $\begin{array}{c}1.162 * * \\
(0.390)\end{array}$ & $\begin{array}{c}0.038 \\
(0.045)\end{array}$ & $\begin{array}{c}1.970 \\
(2.141)\end{array}$ & $\begin{array}{c}-0.002 \\
(0.002)\end{array}$ & $\begin{array}{c}0.196 \\
(4.622)\end{array}$ & $\begin{array}{l}24.281 \text { **** } \\
(7.182)\end{array}$ & -125.728 & $0.139 /(152)$ \\
\hline
\end{tabular}

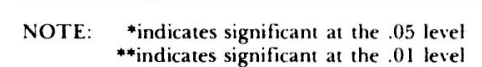

***indicates significant at the .01 level

+indicates coefficients and standard errors for this variable are 100 times their actual values

Standard errors given in parentheses beneath regression coeflicients. 
that whites are not only fleeing the older central cities for the suburban ring, leaving the core to newly arrived minorities, but are leaving such metropolitan areas altogether. The temperature variables proved significant, particularly for the older age groups, and removed some, though not all, of the regional effects. It seems that retired whites either have a greater preference for or have more ability to purchase climatic amenities than do retired blacks. This model shows a very sharp increase in its ability to explain the mobility of the oldest whites. For younger blacks mobility is more readily accounted for, owing to the effect of AFDC payments, and the smaller influence of climate. Of course another reason for the overall weakness of this model may be its failure to include "better" amenity variables relevant to inter-SMSA moves.

\section{ECOLOGICAL ADJUSTMENT: MODEL III}

The third model used to test migration takes its theory from human ecology. The ecological study of migration is concerned with the net adjustment of population and economic/social structure within and between communities, an approach which dates to the work of R. E. Park, R. D. McKenzie and other members of the early Chicago school of sociology. Migration and the adjustment of demographic sub-groups is of particular interest to the ecologist, then, since it bears directly on the potential interactions and institutional arrangements that may develop (or change) in the local community.

As society and the economy grow more complex and differentiated, demand and supply readjustments in labor, capital, and land take place, with growth in some sectors of the economy and relative decline in others. The migration of any group in the population, then, is a function of the expansion of its employment in a sector of the local (SMSA) economy, as well as the preferences and characteristics of the subgroup itself. That is, a change in the size and location of its "niche" in the metropolitan community is witnessed.

Furthermore, it is postulated that the growth of these sectors is largely exogenous with respect to the population movement, and as opportunity expands (declines) in a given SMSA, wage and income levels are bid up (down) to attract the appropriate size labor force. Through the process of derived demand, the relative labor-intensity of each new or old industry will determine the amount of new migrants required. As sectors continue to grow, wages are maintained continually at a high enough level to induce further labor force migration. This ecological model is akin to the traditional metropolitan expert base approach.

Friedman [4] has described much of the reasoning, which dates to Marshall.

The demand for final products relects directly the "utility" attached to them; the demand for factors does so indirectly, being derived from the demand for final products. The link between the demand for the final product and the demand for factors is closest when the amount of the factor required is rigidly and technically linked to the amount of the product [4, p. 153]. 
This relationship is sketched in Figure 1. With some care as to units we have a simple supply and demand graph. Labor is the derived factor of particular interest here. The DD curve represents the "final" demand for the good in question. The $S^{*} \mathrm{~S}^{*}$ curve is drawn for all but one factor of production (labor). If we subtract the supply curve $\mathrm{S} * \mathrm{~S} *$ from the final demand curve DD, we obtain the derived demand curve dd for the nth factor, labor.

Of special interest to us here is the elasticity of derived demand-the percentage change in quantity demanded in response to a percentage change in price. Hicks $[7$, p. 244] gives the elasticity relation in this particular case as:

$$
\begin{aligned}
\lambda= & \frac{\sigma(\mu+\epsilon)+\kappa \epsilon(\mu-\sigma)}{\mu+\epsilon-\kappa(\mu-\sigma)} \\
\lambda= & \text { elasticity of demand for the factor A (derived) } \\
\mu= & \text { elasticity of demand for the product } \\
\epsilon= & \text { elasticity of supply for another input } \mathrm{B} \\
\sigma= & \text { elasticity of substitution between } \mathrm{A} \text { and } \mathrm{B} \\
\kappa= & \mathrm{P}_{\mathrm{A}} \cdot \mathrm{A} / \mathrm{P}_{\mathrm{X}} \cdot \mathrm{X}, \mathrm{A} \text { 's proportionate share in the final product, } \\
& 0<\kappa<1 .
\end{aligned}
$$

This equation gives Marshall's rules of derived demand [7, p. 242]:"

1. Demand is more elastic the more readily substitutes are available $(\partial \lambda / \partial \sigma:(1-\kappa)>0)$

2. Elasticity of derived demand is larger the larger the elasticity of demand for the final product. $(\partial \lambda / \partial \mu: \kappa>0)$

3. Derived demand is more elastic the more elastic is the supply of other factors $(\partial \lambda / \partial \epsilon: \kappa(1-\kappa)>0)$

4. The smaller the fraction of total costs of the factor the less elastic its demand (not universally true) $\quad(\partial \lambda / \partial \kappa:(\mu-\sigma)(\mu+\epsilon)(\epsilon+\sigma))$

Under a few fairly reasonable assumptions about the labor force and changes in sectors of the economy, we can use these rules to make predictions about metropolitan growth and migration.

Figure 1 shows what this means for wages and potential migration to the locations of new industries. Suppose there exists growth in aggregate demand (from DD to $\mathrm{D}^{\prime} \mathrm{D}^{\prime}$ ) with no change in the shape of the demand schedule itself. Then the $\mathrm{dd}$ and $\mathrm{d}^{\prime} \mathrm{d}^{\prime}$ curves (also parallel) represent the corresponding demand functions for the derived factor. As final demand shifts outward, derived demand does so also, pushing up the wage rate from w to $w^{\prime}$ where it intersects with the labor supply curve ss. This wage rise induces migration from other areas, and with time, the labor supply would shift out, etc., establishing a new equilibrium. If exogenous demand continues to grow for this location-specific industry, wages will continue to remain above equilibrium level, inducing additional migration. In another 
Figure 1

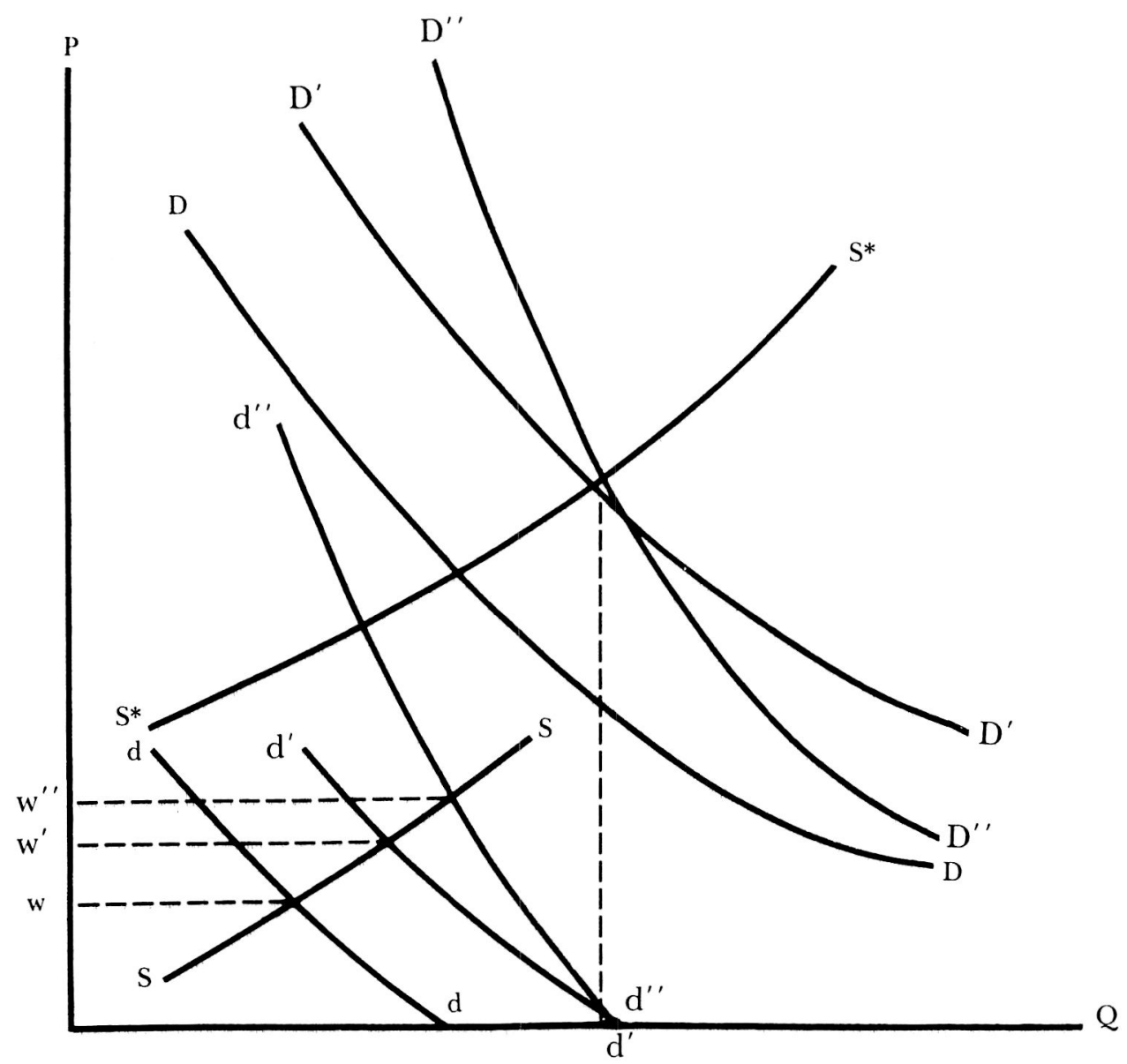

$D D$ curve: initial demand for final product (1);

$D^{\prime} D^{\prime}$ curie: demand for product after growth (2);

$D^{\prime \prime} D^{\prime \prime}$ curve: demand for a second, more inelastic product (3);

$S * S *$ curve: supply of $n-1$ factors of production;

SS curve: supply of labor

$d d$ curve: derived demand for labor under condition (1);

$d^{\prime} d$ ' curie: derived demand for labor under condition (2);

$d^{\prime \prime} d^{\prime \prime}$ curve: derived demand for labor under condition(3);

w: wage of labor under condition (1);

$w^{\prime}$ : wage of labor under condition (2);

$w^{\prime \prime}$ : wage of labor under condition (3);

industry, where final demand is more inelastic (characterized by the $D^{\prime \prime} D^{\prime \prime}$ curve), the $d^{\prime \prime} d^{\prime \prime}$ curve is derived and an even higher wage $\left(w^{\prime \prime}\right)$ is produced. In industries characterized by low elasticity of substitutionthat is, it is not easy to substitute other factors of production for labor-the derived demand would be relatively steeper still. In less abstract terms, 
what the model suggests is that those industries which are characterized by an inelastic demand for their final product and/or grow th in final demand, and perhaps by an inability to substitute away from labor in production, will offer wages high enough to attract laborers from other locales. Those SMSAs with heavy concentration of these growing industries will experience net inmigration.

The economy is commonly divided into primary, secondary, and tertiary sectors representing the extractive, processing, and service industries, respectively. "Higher," or tertiary, levels of the economy (especially in their initial stages of growth) are much more labor intensive. Primary and secondary industries are not growing as quickly and have experienced considerable capital substitution for labor.

The implications of our derived demand exigesis for interregional movement is that those SMSAs with a greater specialization and/or higher productivity in the latter sectors should be experiencing the most substantial net inmigration. This is the ecological hypothesis to be tested. As the infrastructure of the metropolitan community shifts, the effects are seen directly on its population structure and dynamics as a new equilibrium is attained. Rather than attempting to fabricate measures of the various sectors, simple earnings in a few industries, measured by the following variables, are entered into the equations:

AGR70C per capita SMSA earnings 1970 in agriculture;

CON70C per capita SMSA earnings 1970 in construction;

MAN70C per capita SMSA earnings 1970 in manufacturing;

TRAN70C per capita SMSA earnings 1970 in transportation;

TRAD70C per capita SMSA earnings 1970 in wholesale/retail trade;

GOV70C per capita SMSA earnings 1970 in government.

The use of earnings by industry, while not ideal, does make some improvement upon some of the aggregate economic base indicators used by others. A priori expectations are that all coefficients are positive with the possible exception of agriculture. Government and services (both labor intensive and growing) should both be positive and highly significant. Manufacturing and transport will figure less importantly since they are older and less labor intensive.

Results. As Table 3 indicates, the ecological model performs respectably. The service sector is significant and positive across all ages, especially for whites. Transportation and agriculture were found to be negatively related to migration for the body of the labor force. Although not significant, the coefficient of construction was positive for whites and negative for blacks. Trade was important for younger persons, both black and white. Manufacturing was highly positive in relation to migration for the younger cohorts, and was especially so for blacks. A $\$ 100$ per capita increase in manufacturing earnings predicts an increase of nearly four points in the 
TABLE 3. Model III-Ecological Adjustment

\begin{tabular}{|c|c|c|c|c|c|c|c|c|c|c|c|}
\hline AGE GROUP & $\mathrm{AGR70C}$ & $\operatorname{CON} 70 \mathrm{C}$ & MAN70C & TRAN70C & TRAD70C & SERV70C & GOV70C & SOUTH & WEST & Const. & $\mathrm{R}^{2} /(\mathrm{N})$ \\
\hline \multicolumn{12}{|l|}{ White Males } \\
\hline 25-29 & $\begin{array}{r}-47.059^{*} \\
(22.303)\end{array}$ & $\begin{array}{c}40.734 \\
(31.697)\end{array}$ & $\begin{array}{r}12.232 * \\
(5.076)\end{array}$ & $\begin{array}{r}-54.313^{*} \\
(25.275)\end{array}$ & $\begin{array}{l}70.831^{* *} \\
(21.878)\end{array}$ & $\begin{array}{l}64.486^{* * *} \\
(15.110)\end{array}$ & $\begin{array}{l}9.652 \\
(5.993)\end{array}$ & $\begin{array}{c}9.689^{*} \\
(3.906)\end{array}$ & $\begin{array}{c}16.607 * * \\
(5.292)\end{array}$ & -61.754 & $0.315 /(206)$ \\
\hline $30-34$ & $\begin{array}{c}-13.412 \\
(20.701)\end{array}$ & $\begin{array}{l}-2.334 \\
(29.420)\end{array}$ & $\begin{array}{c}17.893 * * * \\
(4.711)\end{array}$ & $\begin{array}{c}17.036 \\
(23.459)\end{array}$ & $\begin{array}{c}40.531 * \\
(20.307)\end{array}$ & $\begin{array}{l}52.131^{* * *} \\
(14.023)\end{array}$ & $\begin{array}{c}-34.838^{* * *} \\
(5.564)\end{array}$ & $\begin{array}{c}8.847 * \\
(3.625)\end{array}$ & $\begin{array}{l}22.707 * * * \\
(4.912)\end{array}$ & -37.004 & $0.486 /(206)$ \\
\hline 35-39 & $\begin{array}{c}-17.448 \\
(14.055)\end{array}$ & $\begin{array}{c}8.511 \\
(19.976)\end{array}$ & $\begin{array}{l}6.839^{*} \\
(3.199)\end{array}$ & $\begin{array}{c}-13.031 \\
(15.927)\end{array}$ & $\begin{array}{c}13.377 \\
(13.788)\end{array}$ & $\begin{array}{c}26.219^{* *} \\
(9.522)\end{array}$ & $\begin{array}{c}-7.178 \\
(3.778)\end{array}$ & $\begin{array}{l}5.630 * \\
(2.462)\end{array}$ & $\begin{array}{l}17.510^{* * * *} \\
(3.335)\end{array}$ & -20.184 & $0.206 /(206)$ \\
\hline $40-44$ & $\begin{array}{c}-15.763 \\
(10.734)\end{array}$ & $\begin{array}{c}10.074 \\
(15.256)\end{array}$ & $\begin{array}{l}2.585 \\
(2.443)\end{array}$ & $\begin{array}{r}-26.898^{*} \\
(12.165)\end{array}$ & $\begin{array}{c}5.806 \\
(10.530)\end{array}$ & $\begin{array}{c}22.306^{* *} \\
(7.273)\end{array}$ & $\begin{array}{c}-5.490 \\
(2.885)\end{array}$ & $\begin{array}{c}3.351 \\
(1.880)\end{array}$ & $\begin{array}{l}12.242 * * * \\
(2.547)\end{array}$ & -6.590 & $0.173 /(206)$ \\
\hline $45-49$ & $\begin{array}{c}-9.985 \\
(9.940)\end{array}$ & $\begin{array}{c}13.678 \\
(13.361)\end{array}$ & $\begin{array}{l}0.426 \\
(2.140)\end{array}$ & $\begin{array}{r}-26.406 * \\
(10.654)\end{array}$ & $\begin{array}{c}1.611 \\
(9.222)\end{array}$ & $\begin{array}{c}22.139^{* * *} \\
(6.369)\end{array}$ & $\begin{array}{r}-5.099 * \\
(2.527)\end{array}$ & $\begin{array}{c}2.226 \\
(1.647)\end{array}$ & $\begin{array}{l}8.981 * * * \\
(2.231)\end{array}$ & -5.201 & $0.158 /(206)$ \\
\hline 50-59 & $\begin{array}{c}-3.905 \\
(7.027)\end{array}$ & $\begin{array}{l}12.044 \\
(9.988)\end{array}$ & $\begin{array}{c}-1.083 \\
(1.599)\end{array}$ & $\begin{array}{r}-20.456^{*} \\
(7.964)\end{array}$ & $\begin{array}{c}-1.357 \\
(6.894)\end{array}$ & $\begin{array}{c}16.259^{* * *} \\
(4.761)\end{array}$ & $\begin{array}{r}-4.615^{*} \\
(1.889)\end{array}$ & $\begin{array}{l}1.329 \\
(1.231)\end{array}$ & $\begin{array}{l}6.657^{* * * *} \\
(1.668)\end{array}$ & -1.530 & 0. $162 /(206)$ \\
\hline $60-69$ & $\begin{array}{c}7.849 \\
(9.908)\end{array}$ & $\begin{array}{c}13.576 \\
(14.081)\end{array}$ & $\begin{array}{c}-8.386^{* * *} \\
(2.255)\end{array}$ & $\begin{array}{r}-24.473 * \\
(11.228)\end{array}$ & $\begin{array}{c}-10.535 \\
(9.714)\end{array}$ & $\begin{array}{c}9.935 \\
(6.712)\end{array}$ & $\begin{array}{c}-9.538^{* * *} \\
(2.663)\end{array}$ & $\begin{array}{l}3.559^{*} \\
(1.735)\end{array}$ & $\begin{array}{l}10.058^{* * *} \\
(2.351)\end{array}$ & 10.899 & $0.244 /(206)$ \\
\hline $70+$ & $\begin{array}{c}18.739 \\
(10.146)\end{array}$ & $\begin{array}{c}17.395 \\
(14.420)\end{array}$ & $\begin{array}{c}-10.199 * * * \\
(2.309)\end{array}$ & $\begin{array}{c}-39.221^{* * *} \\
(11.498)\end{array}$ & $\begin{array}{c}-8.366 \\
(9.953)\end{array}$ & $\begin{array}{c}13.039 \\
(6.874)\end{array}$ & $\begin{array}{c}-11.345 * * * \\
(2.727)\end{array}$ & $\begin{array}{l}5.743^{* *} \\
(1.777)\end{array}$ & $\begin{array}{c}13.631^{* * *} \\
(2.408)\end{array}$ & 11.824 & $0.387 /(206)$ \\
\hline
\end{tabular}


TABLE 3. Model III-Ecological Adjustment (Cont.)

\begin{tabular}{|c|c|c|c|c|c|c|c|c|c|c|c|}
\hline AGE GROUP & P AGR70C & CON70C & MAN70C & TRAN70C & TRAD70C & SERV70C & GOV70C & SOUTH & WEST & Const. & $\mathrm{R}^{2} /(\mathrm{N})$ \\
\hline \multicolumn{12}{|l|}{ Black Males } \\
\hline $25-29$ & $\begin{array}{c}-68.801 \\
(42.623)\end{array}$ & $\begin{array}{c}-32.719 \\
(59.785)\end{array}$ & $\begin{array}{l}39.361^{* * * *} \\
(10.163)\end{array}$ & $\begin{array}{r}-87.026 \\
(47.117)\end{array}$ & $\begin{array}{l}138.475 * * * \\
(43.633)\end{array}$ & $\begin{array}{r}96.303 * * \\
(36.171)\end{array}$ & $\begin{array}{l}45.158 * * * \\
(11.264)\end{array}$ & $\begin{array}{c}-35.677 * * * \\
(7.674)\end{array}$ & $\begin{array}{l}27.181^{*} \\
(11.880)\end{array}$ & -100.647 & $0.488 /(167)$ \\
\hline $30-34$ & $\begin{array}{c}-8.651 \\
(31.352)\end{array}$ & $\begin{array}{c}-15.176 \\
(43.280)\end{array}$ & $\begin{array}{c}36.946 * * * \\
(7.419)\end{array}$ & $\begin{array}{l}-6.412 \\
(32.733)\end{array}$ & $\begin{array}{l}91.145^{* *} \\
(31.708)\end{array}$ & $\begin{array}{c}57.671 * \\
(28.828)\end{array}$ & $\begin{array}{c}15.410 \\
(8.305)\end{array}$ & $\begin{array}{c}-21.189 * * * \\
(5.593)\end{array}$ & $\begin{array}{c}-3.406 \\
(8.596)\end{array}$ & -83.352 & $0.473 /(169)$ \\
\hline $35-39$ & $\begin{array}{c}-2.171 \\
(22.436)\end{array}$ & $\begin{array}{c}-19.828 \\
(30.969)\end{array}$ & $\begin{array}{l}19.819 * * * \\
(5.259)\end{array}$ & $\begin{array}{r}3.289 \\
(23.816)\end{array}$ & $\begin{array}{l}40.453 \\
(22.305)\end{array}$ & $\begin{array}{c}37.947 * \\
(18.159)\end{array}$ & $\begin{array}{c}20.716^{* * * *} \\
(5.842)\end{array}$ & $\begin{array}{r}-10.084 \\
(3.986)\end{array}$ & $\begin{array}{l}2.816 \\
(6.109)\end{array}$ & -53.423 & $0.292 /(165)$ \\
\hline $40-44$ & $\begin{array}{r}-17.548 \\
(16.513)\end{array}$ & $\begin{array}{l}-6.852 \\
(22.603)\end{array}$ & $\begin{array}{c}11.238^{* *} \\
(3.940)\end{array}$ & $\begin{array}{c}-10.085 \\
(17.589)\end{array}$ & $\begin{array}{c}33.957 * \\
(16.382)\end{array}$ & $\begin{array}{c}-0.447 \\
(13.591)\end{array}$ & $\begin{array}{c}1.502 \\
(4.312)\end{array}$ & $\begin{array}{r}-4.654 \\
(2.976)\end{array}$ & $\begin{array}{c}16.581 * * * \\
(4.670)\end{array}$ & -19.183 & $0.254 /(163)$ \\
\hline $45-49$ & $\begin{array}{c}-16.437 \\
(15.431)\end{array}$ & $\begin{array}{c}2.091 \\
(21.683)\end{array}$ & $\begin{array}{l}7.302 \\
(3.812)\end{array}$ & $\begin{array}{r}-33.383^{*} \\
(16.780)\end{array}$ & $\begin{array}{l}18.835 \\
(15.745)\end{array}$ & $\begin{array}{c}17.835 \\
(12.898)\end{array}$ & $\begin{array}{c}0.323 \\
(4.132)\end{array}$ & $\begin{array}{c}-9.107 * * \\
(2.888)\end{array}$ & $\begin{array}{l}3.798 \\
(4.354)\end{array}$ & -8.408 & $0.233 /(163)$ \\
\hline $50-59$ & $\begin{array}{r}-28.890 \\
(15.189)\end{array}$ & $\begin{array}{c}-4.448 \\
(21.507)\end{array}$ & $\begin{array}{c}3.879 \\
(3.587)\end{array}$ & $\begin{array}{c}-26.420 \\
(16.467)\end{array}$ & $\begin{array}{c}6.988 \\
(15.340)\end{array}$ & $\begin{array}{c}20.489 \\
(12.512)\end{array}$ & $\begin{array}{c}-1.699 \\
(3.972)\end{array}$ & $\begin{array}{c}-4.293 \\
(2.709)\end{array}$ & $\begin{array}{l}6.665 \\
(4.134)\end{array}$ & -2.450 & $0.098 /(172)$ \\
\hline $70+$ & $\begin{array}{c}-46.045^{* *} \\
(17.095)\end{array}$ & $\begin{array}{l}-1.595 \\
(23.378)\end{array}$ & $\begin{array}{c}-2.997 \\
(4.075)\end{array}$ & $\begin{array}{r}-17.265 \\
(17.740)\end{array}$ & $\begin{array}{c}-11.936 \\
(16.799)\end{array}$ & $\begin{array}{c}19.058 \\
(14.425)\end{array}$ & $\begin{array}{l}-4.125 \\
(4.603)\end{array}$ & $\begin{array}{r}-2.110 \\
2.954\end{array}$ & $\begin{array}{c}22.810 * * * \\
(4.972)\end{array}$ & 10.463 & $0.135 /(162)$ \\
\hline
\end{tabular}

Note: *indicates significant at the .05 level

$* *$ *indicates significant at the .01 level
$* * *$ indicates significant at the .001 level

Standard errors given in parentheses beneath regression coefficients. 
net migration rate of black males ages 25-29. If non-white progress through the hierarchy of sectors in the economy proceeds with some lag after whites, the importance of manufacturing here is not surprising. Older age groups, though, seem to find heavy manufacturing cities unpleasant places.

Curiously, the public sector earnings were very strongly negatively related to most white movement, and positively related to black mobility. This surprising result was due in part, it appears, to the inclusion of military earnings in the government totals. A revision of the model which separated military and non-military government earnings gave these results: armed forces earnings were negatively related across almost all groups (and significant for most whites with the notable exception of blacks aged 25-29, where the coefficient was positive and highly significant. For both whites and blacks aged 20-24 (equations not shown) this variable was the most significant, indicating entry into the armed forces in the recent past. For white, non-military government earnings were positively related to mobility for ages 25-29 (significant only for 25-29), and negative and significant for the two oldest age groups. For blacks, on the other hand, the variable was positively signed for all age groups, very significant for 30-39 year olds $(\alpha<.001)$ while insignificant for others.

In other versions of the model, neither the addition of a per capita income variable nor an income change variable improved the fit. A version which regressed migration on percent change in the several variables yielded results approximately the same as those discussed above. The regional dummies for this model continue to absorb a good deal of otherwise unexplained variance. Adjusted $\mathrm{R}^{2}$ values compare moderately well with the other models, though no noteworthy pattern emerges in the variance explained, which is low for middle-aged whites, and declines steadily with age for blacks.

\section{CONCLUSIONS}

In conclusion, the three models themselves are assessed. In a strict statistical sense, it is not possible to compare the significance of the several equations which incorporate both different variables and different numbers of parameters, but some useful inferences can still be made.

Model I has confirmed the basic validity of the human capital framework in the analysis of migration, and demonstrated the variety of at least partially independent economic phenomena to which potential migrants respond. The analysis of the model indicates that effects are not consistent across all variables (for example, different 1960 and 1970 unemployment rate effects by race), suggesting that one should search carefully for the mechanism through which this variable really operates. As some differential effects for earnings by race showed, we cannot conclude that individuals are moving in response merely to income levels prevailing in the regions around the country. Migrants are aware of what wages prevail for their particular livelihood in other cities. This suggests that disaggregation of the migrant population in conjunction with a finer 
breakdown of the variables for occupational earnings might produce some very fruitful results in later work.

A test of the effect of non-traded goods had the most parameters of any model, yet for younger and even middle-aged whites the model is very weak. For older whites and for blacks the model does slightly better because of the inclusion of measures of climate and welfare payments, respectively. While increasing attention has been focused recently on patterns of movement due to "amenities," this only holds for a segment of the population. Among many of the older age groups, especially those living on fixed incomes, low cost of living is a particularly important amenity resource. In virtually all the equations examined, the coefficient of the income variable for the oldest age groups is negative, indicating a migration out of high cost (highly correlated with high income) areas to places where one's retirement check can go farther.

The implications of Model III are that cities with high concentrations of services are attracting substantial numbers of migrants (more whites than blacks). Manufacturing is still a central cause of population growth, though here the effect is more pronounced for blacks than for whites. Effects of governmental earnings were neither strong nor consistent (even after correction for military earnings), suggesting that work needs to be done in analyzing this component further. That whites and blacks react in opposite directions with respect to construction may be due not so much to response to job opportunities, but rather to the kinds of cities to which each is moving (whites move to the faster-growing cities). This agrees with the findings of Model I regarding city age and density for race groups.

The findings of Model II I are instructive, particularly since the variables it contains are economic, but are not strictly wage or income measures. Its predictive power lends credence to the concept of ecological adjustment: the population balance of cities continues to shift, driven by corresponding shifts in economic structure of the region as a whole. What the implications are of the selective redistribution of population in this fashion is not clear. It has not been determined whether intermetropolitan age/race segregation or integration is taking place as a result of this process.

Fairly good fits of both the capital model and the ecological model suggest that the derived demand discussion above provides some hint as to how these two models might be combined. The changing economic infrastructure of the region is the driving force of migration, but it translates directly into wage effects, which are the ones to which potential migrants respond. A more definitive test of this suggestion might be made by linking age/occupation-specific migration patterns to local occupational earnings differentials, and linking these in turn to the changing ecological balance of the respective communities.

The superiority of these two models to Model II suggests that the lion's share of interregional population movement takes place in the search for the traditional forms of economic gain. The consumption of amenities (and other non-tradeable goods) can certainly not be discounted, however. For persons less tied to the heart of the labor force, such factors loom large in importance. High income levels and the consumption of more leisure 
have led to an ability on the part of the populace to be more selective in their choice of permanent residence and place of retirement. If incomes continue to rise, the demand for non-traded amenities will occupy an increasingly influential position in regional population shifts.

One of the most interesting features of the research is the fact that we cannot explain away the regional effects in the models. This is especially true of white movement to the West. This phenomenon suggests that beyond all the economic and even amenity variables, that have been tested, there is something else that is pushing or pulling a substantial number of persons from one region of the country to another. At best, social and cultural "variables" receive only lip service from most authors, but it appears that these admittedly more nebulous entities constitute a considerable influence on persons' decisions to migrate.

A few comments on the general demographic character of the regression results can be made. Differences by race which persist include: (a) much greater response on the part of blacks to AFDC payments; (b) some residual differences in regional movements, out of the South for blacks, and toward the West for whites; and (c) some lag of blacks behind whites in their progress through the economic structure, as indicated by the larger effect of manufacturing and the smaller response to amenities. Differences by age which persist include (a) more responses among younger cohorts to income differences, which accords with human capital theory; and (b) the pattern of goodness of fit which declines and then rises for whites, and declines steadily for blacks.

This paper was intended to remedy a few of the weaknesses of earlier research-to which it compares favorably both in terms of overall goodness of fit, and the effects of specific variables-by developing and testing a series of theoretically grounded models of net metropolitan migration. Testing several versions of each model on a single body of data lends more credence to inferences drawn from the results. The omission of several cities due to incomplete data or the fact that there were several outliers is unfortunate, but values for those cases do not contradict the basic patterns followed by the included data.

Although this analysis has used essentially the same data as Hinze [8], some different results are obtained. Hinze does not separate sex, and collapses age into 15-year groups. In particular, he notes highly significant effects for several economic variables, including decade percent change in manufacturing, services, wholesaling, and farm sales, but this may be due to their correlation with population increase itself. He also finds that an age-specific composition variable is positive and significant, but this reveals little about causality. In equations for blacks, this study obtained statistically more significant results for welfare and economic structure variables. Both studies give similar results for the effects of city age, climate, unemployment, and income.

Simultaneity bias and multicollinearity are two potential statistical problems that arise in these models. My general findings do not contradict those obtained by others who have used simultaneous methods of estimation. If simultaneity is present, it would perhaps downwardly bias many of 
the coefficients (such as unemployment), and have no effect on several others (including the climatological variables). Some of the social welfare measures (AFDC70, EDUC67) as well as a few of the tertiary sector employment variables are more likely to be upwardly biased. In some of the equations, independent variables are correlated. Multicollinearity will raise the standard errors of the coefficients without biasing them. Consequently, it is difficult to disentangle the effects of certain competing variables, since it was impossible to increase the sample size, and it seemed inappropriate to eliminate any particular variable.

It is clear that migrants are very selective in their responses to economic or other variables. Disaggregation of the migrant groups is advisable. Further disaggregation by income level, labor force participation, and occupation would reveal a wealth of information about interregional population shifts. Explanation of the recent (1970-75) shifts in migration-net outflow from many metropolitan areas-remains problematic. These models, I suspect, would not adequately predict these changes, although the data for the independent variables has not been collected for such a test. Nevertheless, different time periods with the same models would be profitable. One could then assess (a) long-run versus short-run effects of exogenous influences, and (b) longitudinal changes in the entire migration system itself. Finally, some effort needs to be directed toward exploring the effects of additional non-pecuniary variables.

\section{FOOTNOTES}

${ }^{1}$ The net migration rates used here were calculated by Hinze using the forward census survival ratio method:

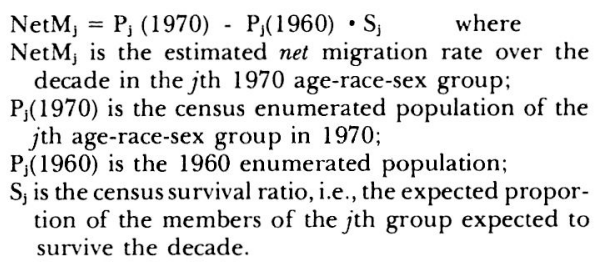
decade in the $j$ th 1970 age-race-sex group;

$\mathrm{P}_{\mathrm{j}}(1970)$ is the census enumerated population of the $j$ th age-race-sex group in 1970 .

$P_{j}(1960)$ is the 1960 enumerated population;

$\mathrm{S}_{\mathrm{j}}$ is the census survival ratio, i.e., the expected proportion of the members of the $j$ th group expected to survive the decade.

See Hinze [8, p. 115-118] for more details on computation of rates and alternative interpretation of other formulae. Shryock and Siegel [12, p. 616-672] give a more extended discussion of the various methods of estimating internal migration. The data used in this paper are unpublished and are more detailed than that given by Hinze. The author is grateful to Mr. Hinze for permission to use the data.
${ }^{2}$ Actually, movement will only take place when wages at $\mathrm{B}$ are high enough to cover moving costs, but this fact may easily be incorporated into the main body of the theory. Some regional wage differentials may be expected to persist due to these costs.

${ }^{3}$ The zero order correlation between percent change in unemployment with SOUTH dummy is -0.271 ; with WEST it equals 0.402 .

${ }^{4}$ Zero order correlation of TAX67 with these other variables are: PROFM70 (0.621), LABM70 (0.567), CLERF70 (0.408), SOUTH (-0.626), and WEST (0.330).

${ }^{5}$ This discussion speaks to Marshall's laws (1) and (2). If we were willing to assume an inelast ic supply of other factors, and a small fraction of total costs for our factor, the derived demand curve would be steeper still. These have little empirical justification in this context. With respect to the fourth law one finds that while there is stronger inducement for labor to move (higher wages), not much total labor (quantity) is demanded. This is also often referred to as "joint" supply or demand.

\section{REFERENCES}

1. Becker, G.S. "Investment in Human Capital: A Theoretical A nalysis," Journal of Political Economy, 70 (October, 1962), 9-49.

2. Bowles, S. "Migration as Investment," Review of Economics and Statistics, 52 (November, 1970), 356-363.

3. Cebula, R.J. "Migration, Economic Opportunity, and the Quality of Life: An Analysis According to Race, Sex, and Age," Annals of Regional Science, 9 (March, 1959), 127-133.
4. Friedman, M. Price Theory, Chicago: Aldine, 1976.

5. Graves, P. E. "Migration and Climate," Mimeo, University of Chicago Department of Economics, 1976.

6. Greenwood, M.J. Research on Internal Migration in the United States: A Survey," Journal of Economic Literature, 13 (June, 1975), 397-433.

7. Hicks, J. R. The Theory of Wages, London: Macmillan, 1932 
8. Hinze, K. E. Causal Factors in the Net Migration Flow to Metropolitan Areas of the United States 1960-1970, Chicago: Community and Family Study Center, 1977.

9. Lowry, I.S. Migration and Metropolitan Growth, San Francisco: Chandler, 1966.

10. Marshall, A. Principles of Economics, London: Macmillan, 1961.

11. Schwartz, A. "Migration, Age, and Education," Journal of Political Economy, 84 (August, 1976), 701719.
12. Shyrock, H.S., and J.S. Siegel. The Methods and Materials of Demography, Washington, D.C.: U.S. Government Printing Office, 1975.

13. Sjaastad, L. "The Costs and Returns of Human Migration," Journal of Political Economy, 70 (October, 1962), 80-93.

14. Tiebout, C.A. "A Pure Theory of Local Public Expenditures," Journal of Political Economy, 64 (October, 1956), 416-424. 